\title{
Syngas Generation Process Simulation: A Comparative Study
}

\author{
Reyner. P. P. de Oliveira ${ }^{\text {a }}$, Maria E. K. Fuziki ${ }^{\text {b }}$, Priscila M. L. Z. Costa ${ }^{\text {a }}$, Angelo Marcelo Tusset ${ }^{\text {a }}$, \\ Giane G. Lenzi a,1,* \\ ${ }^{a}$ Federal University of Technology - Doutor Washington Subtil Chueire St., 330, Ponta Grossa - Paraná - 84017-220 \\ Brazil \\ b State University of Maringá - Colombo Ave., 5790, Maringá - Paraná - 87020-900 - Brazil \\ 1 gianeg@utfpr.edu.br \\ * Corresponding Author
}

\section{ARTICLE INFO}

\section{Article history}

Received January 24, 2022

Revised March 01, 2022

Accepted March 04, 2022

\section{Keywords}

Dry reforming of methane; Steam reforming of methane; Gibbs energy minimization; Biogas

\begin{abstract}
Methane reforming processes are of great importance for both the reduction of this greenhouse gas concentration in the atmosphere and for hydrogen production for energetic or chemical synthesis purposes. The use of Biogas in substitution for methane in reforming processes still provides a solution for the recovery of organic waste capable of producing Biogas. However, an in-depth analysis of the advantages of this substitution from the point of view of process yield is still lacking. Thus, the main contribution of the present research is the focus given to the comparison between methane and biogas as a reactant for the dry and steam reforming processes. In this work, a computational comparison of syngas production processes was performed, considering the system within the open-loop control. The software Aspen Hysys was used based on the minimization of Gibbs free energy in equilibrium. The parameters studied were: molar ratio of reagents (1-5), temperature $\left(600-1000{ }^{\circ} \mathrm{C}\right)$, and pressure (1-5 bar). Dry methane reforming and steam methane reforming units were simulated, as well as both units using Biogas as a methane source. The plant was built in the simulator, and the results obtained indicated that high values in the molar ratio of $\mathrm{CO}_{2} / \mathrm{CH}_{4}, \mathrm{CO}_{2} / \mathrm{Biogas}, \mathrm{H}_{2} \mathrm{O} / \mathrm{CH}_{4}$, and $\mathrm{H}_{2} \mathrm{O} / \mathrm{Biogas}$, high temperatures, and low pressures favor the maximum conversion of methane. The use of Biogas in replacement of pure methane in the reform process proved to be advantageous for favoring the synthesis gas production reaction, besides adding value to a residue.
\end{abstract}

This is an open-access article under the CC-BY-SA license.

\section{Introduction}

The consumption of fossil fuels had a great increase with industrial and economic development, causing the growth of gas emissions, such as carbon dioxide $\left(\mathrm{CO}_{2}\right)$, into the atmosphere. These gases resulting from the burning of fossil fuels contribute to the intensification of the so-called greenhouse effect, increasing considerably the barrier that prevents the heat output from Earth, producing instability in the planet's energy balance [1]. Thus, the main factor for the development of renewable energy strategies is the concern with the irreversible environmental damage that can occur with the continued or accelerated use of fossil fuels [2].

The main greenhouse gases are $\mathrm{CO}_{2}, \mathrm{CH}_{4}, \mathrm{~N}_{2} \mathrm{O}$, and chlorofluorocarbons. Although a part of greenhouse gas emissions originates from organic waste, most come from carbon dioxide $\left(\mathrm{CO}_{2}\right)$ 
produced as a result of the use of fossil fuels such as coal, oil, and natural gas [3], [4]. Many processes have been studied to neutralize new emissions and generate energy $\left(\mathrm{H}_{2}\right)$.

The most common processes used to generate $\mathrm{H}_{2}$ are hydrocarbon reforms, which produce syngas $\left(\mathrm{CO}\right.$ and $\mathrm{H}_{2}$ ). The most common methane reforming processes for hydrogen production are steam reforming, partial oxidative reforming, auto thermal reforming, dry reforming [5]. In hydrocarbon reform processes, Ni-based catalysts are generally used (Ni-Ce/Al, $\mathrm{Ni}_{2} / \mathrm{Al}_{2} \mathrm{O}_{3}, \mathrm{Ni}(10 \%)-\mathrm{Zr}(90 \%)$, Ni$\mathrm{Co} / \mathrm{Ce}-\mathrm{Al}_{2} \mathrm{O}_{3}[6]-[9]$. The main reactions for the production of hydrogen from methane are indicated in Table 1.

Table 1. Main reactions for the production of hydrogen from methane [10].

\begin{tabular}{cccc}
\hline \multicolumn{2}{c}{ Reaction } & H298K $(\mathbf{K J} \mathbf{m o l})$ \\
\hline R1 & Dry Reforming & $\mathrm{CH} 4+\mathrm{CO} 2 \Leftrightarrow 2 \mathrm{CO}+2 \mathrm{H} 2$ & 247 \\
R2 & Steam Reforming & $\mathrm{CH} 4+\mathrm{H} 2 \mathrm{O} \Leftrightarrow \mathrm{CO}+3 \mathrm{H} 2$ & 206 \\
R3 & Partial Oxidation & $\mathrm{CH} 4+1 / 2 \mathrm{O} 2 \Leftrightarrow \mathrm{CO}+2 \mathrm{H} 2$ & -36 \\
\hline
\end{tabular}

In addition to these more common routes, the production of synthesis gas has been extensively studied, from the use of biogas as a replacement for pure methane as a reagent, since, in some processes, there is a waste of organic materials that generate biogas and thus there is used as raw material [11]-[13]. The composition of the raw biogas is highly dependent on the gross material but mainly consists of 60 and $65 \%$ methane $\left(\mathrm{CH}_{4}\right), 30$ and $35 \%$ carbon dioxide $\left(\mathrm{CO}_{2}\right), 1 \%$ nitrogen $\left(\mathrm{N}_{2}\right)$, and smaller percentages of other gases such as $\mathrm{H}_{2} \mathrm{~S}, \mathrm{H}_{2}$ and water vapor [14]-[16]. Its high methane content allows its use as fuel, that is, as a substitute for natural gas, for heating and energy generation [17]. The biogas, when discarded into the atmosphere, causes numerous damages to the environment.

Some authors have studied the simulation of hydrocarbon reforming processes for energy generation [13], [18], [19]. It is possible to simulate processes such as methane reforming using equilibrium models, which aim to predict the composition of products in chemical equilibrium based on thermodynamic principles. A common approach of these models is the Gibbs free energy minimization (GFEM), which dispenses with detailed knowledge of the reactions involved in the process, requiring only knowing which chemical elements enter the system and the expected products of the overall reaction [20]. Such models are based on the conservation of elements (usually C, H, O, and $\mathrm{N}$ ) and energy (by the assumption of uniform temperatures) associated with the equilibrium criterion by minimizing the Gibbs free energy of the system [21]. Their predictions, however, can present deviations due to the inaccurate assumption that the heat exchanges that occur during the process are reversible and also due to non-equilibrium conditions and transient effects that occur in real processes and that are not properly portrayed by the equilibrium models [20], [21]. Even so, GFEM models have been widely used in the study of methane reforming and other processes. For example, [22] used the GFEM model in the thermodynamic analysis of methane oxidation; [23] studied the partial biogas oxidation using the GFEM principle; while [24] analyzed the methanol synthesis from biogas using the GFEM method. As for the reforming processes, [25] combined the GFEM model with regression analysis to study both steam and dry methane reforming; [26] applied a model based on GFEM to the steam methane reforming in a membrane reactor; [27], in turn, used the GFEM model in the thermodynamic analysis of dry methane reforming, identifying the most favorable conditions of temperature, pressure and $\mathrm{CH}_{4} / \mathrm{CO}_{2}$ ratio.

It is also possible to make use of powerful tools, such as the Aspen Plus ${ }^{\circledR}$ software, to model systems involving complex reactions, since the program is able to calculate the chemical composition at equilibrium by minimizing the Gibbs energy, without the need to specify the stoichiometry of the reactions involved [28]-[30]. Such software has already been used in the study of both dry and steam methane reforming processes [31]-[33], in the presence of the catalyst, in different types of reactors, such as in a fluidized bed membrane reactor [31]. In [34], steam and dry biogas reforming processes were studied using the Aspen Plus ${ }^{\circledR}$ software, focusing on comparing the performance of a conventional reactor and an $\mathrm{H}_{2}$-permeable membrane reactor. For calculations during simulation, the authors used a single Gibbs reactor block (RGIBBS) to represent the conventional reactor, while for 
the membrane reactor, a series of RGIBBS blocks and separators, available in the software, was used. In [28], it was possible to use the same software to determine the composition of the products obtained by oxy-reforming and oxy-steam reforming of biogas. The authors analyzed the effects of temperature (600-800 $\left.{ }^{\circ} \mathrm{C}\right)$, pressure (1-20 atm), and inputs $\left(\mathrm{O}_{2} / \mathrm{CH}_{4}, \mathrm{H}_{2} \mathrm{O} / \mathrm{CH}_{4}\right.$, and $\left.\mathrm{CO}_{2} / \mathrm{CH}_{4}\right)$ and optimized these parameters using a response surface methodology. In [35], the authors have theoretically studied the biogas reform process using the Aspen Plus ${ }^{\circledR}$ software and compared the simulation results with the results obtained experimentally. As possible products, the authors considered $\mathrm{CH}_{4}, \mathrm{CO}_{2}, \mathrm{CO}, \mathrm{H}_{2}, \mathrm{O}_{2}$, $\mathrm{H}_{2} \mathrm{O}$, and solid carbon. The theoretical predictions showed the same trends as the experimental results, although the latter presented lower conversion values than those predicted by the equilibrium model, which the authors attributed to mass and heat transfer limitations. Another interesting application was made by [36], who also modeled the reform process using Aspen Plus® software, to study the application of biogas in solid oxide fuel cells (SOFC).

In this context, the present research contributes to the field by carrying out a study focused on the comparison between methane and biogas as reactants in both dry and steam reforming processes, an approach that has not yet been fully explored. For this purpose, simulations based on the Gibbs free energy minimization model were performed in the Aspen Hysys software, as described in the Material and Methods section. Operational parameters of the reforming process, such as the molar ratio of reactants, temperature, and pressure, were varied in the simulations. In the Results and Discussions section, the effects of these variations are analyzed in detail.

\section{Materials and Methods}

The comparative study of methane and Biogas as raw materials for the dry/steam reforming processes was carried out through simulations in the Aspen Plus software. In the following sections, the simulation conditions and the evaluated parameters are described in detail.

\subsection{Simulation with Aspen Plus}

The study of the synthesis gas production was carried out through four different processes: dry reforming of methane, steam reforming, and both reforms using biogas as a replacement for pure methane in the form of a reagent. Biogas is a material that does not exist in the Aspen Hysys database. This component was inserted through its composition information. Biogas with $70 \% \mathrm{CH}_{4}$ and $30 \%$ $\mathrm{CO}_{2}$. The syngas production was studied by varying the inlet currents and the parameters of temperature, molar ratio, and pressure.

The thermodynamic package used in all process simulations was the Peng Robinson. It is an ideal model for specific mass calculations of liquids in hydrocarbon systems as well as liquid-vapor equilibrium calculations [37]. The reactions used in the methane reform processes were reactions R1 and R2 (Table 1). All reactions were added to the software during the simulation considering stoichiometry and thermodynamic conditions, and the chemical equilibrium was calculated using the Gibbs minimization model, which according to the research, was the most suitable for a study involving multiples equipment operating within certain operational limits [38]. The compounds were: methane $\left(\mathrm{CH}_{4}\right)$, hydrogen $\left(\mathrm{H}_{2}\right)$, nitrogen $\left(\mathrm{N}_{2}\right)$, carbon dioxide $\left(\mathrm{CO}_{2}\right)$, and carbon monoxide $(\mathrm{CO})$.

\subsection{Dry Reforming of Methane}

To simulate the dry reforming of methane, the operational conditions at the flow rates of the input streams of $\mathrm{CH}_{4}$ and $\mathrm{CO}_{2}$ were defined based on the literature [39]-[42] and are presented in Table 2. In addition to the reagents, an input stream of nitrogen $\left(\mathrm{N}_{2}\right)$ was added as carrier gas. An equilibrium reactor developed following the Gibbs thermodynamic model was used, where the thermodynamic equilibrium calculations of the system are based on the minimization of the Gibbs free energy. The reaction used in the simulation was the main dry reforming reaction (R1). The reaction that forms carbon deposition was neglected due to the temperature used, which makes its formation insignificant. The dimensions of the reactor used were $4 \mathrm{~m}$ high and diameter equal to $1 \mathrm{~m}$.

The flowsheet for dry reforming of methane is shown in Fig. 1. The inlet streams were mixed at a ratio of $\mathrm{CO}_{2} / \mathrm{CH}_{4}=1$ and preheated to a temperature of $100^{\circ} \mathrm{C}$. The resulting mixture was fed into the ERV-100 reactor that simulates the characteristics of a continuous tubular (PBR). The reforming 
reaction is endothermic and operated at $650{ }^{\circ} \mathrm{C}$. After the end of the reaction, the steam was cooled to a temperature of $50{ }^{\circ} \mathrm{C}$, and the syngas and residual reactants separated.

Table 2. Specifications for the input streams - Dry Reform

\begin{tabular}{cccc}
\hline Parameter & $\mathbf{N}_{\mathbf{2}}$ & $\mathbf{C O}_{\mathbf{2}}$ & $\mathbf{C H}_{\mathbf{4}}$ \\
\hline Flow rate $(\mathrm{kgmol} / \mathrm{h})$ & 200 & 1000 & 1000 \\
Temperature $\left({ }^{\circ} \mathrm{C}\right)$ & 25 & 25 & 25 \\
Pressure $(\mathrm{Bar})$ & 1 & 1 & 1 \\
\hline
\end{tabular}

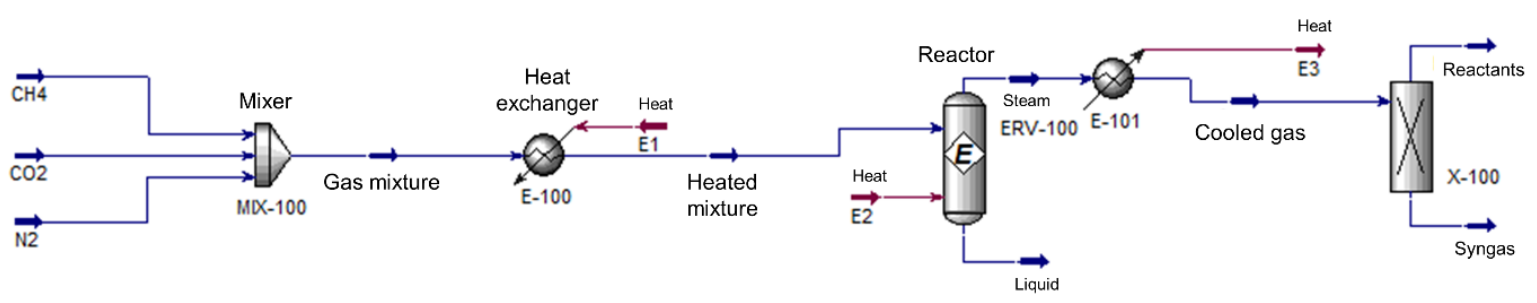

Fig. 1. Aspen HYSYS flow-sheet for dry reforming of Methane.

\subsection{Steam Reforming of Methane}

The procedure used for the simulation of steam reforming was similar to that of dry reforming, based on the work of [43]-[45]. The components added to the simulator were: methane, water, carbon monoxide, and hydrogen. The operating conditions of the input currents of the $\mathrm{CH}_{4}$ and $\mathrm{H}_{2} \mathrm{O}$ reagents are shown in Table 3.

Table 3. Specifications for the input streams - Steam Reforming

\begin{tabular}{ccc}
\hline Parameter & $\mathbf{H}_{2} \mathbf{O}$ & $\mathbf{C H}_{4}$ \\
\hline Flow rate $(\mathrm{kgmol} / \mathrm{h})$ & 1000 & 1000 \\
Temperature $\left({ }^{\circ} \mathrm{C}\right)$ & 25 & 25 \\
Pressure $(\mathrm{Bar})$ & 1 & 1 \\
\hline
\end{tabular}

For the simulation, we considered, as in the previous process, the equilibrium reactor based on the Gibbs thermodynamic model. The reaction used in the simulation was the main steam reforming reaction (R2). Again, the reaction that forms carbon deposition as a function of the temperature used for the reaction $\left(650^{\circ} \mathrm{C}\right)$ was neglected. The reactor used was similar to the dry reform process, a continuous tubular (PBR), previously described. The flowchart was constructed as shown in Fig. 2, and the operational conditions mentioned above were added according to what was found in the literature. The influence of parameters such as temperature, pressure, and molar ratio of the reagents was evaluated. The inlet streams were preheated to a temperature of $100{ }^{\circ} \mathrm{C}$ and mixed in an $\mathrm{H}_{2} \mathrm{O} / \mathrm{CH}_{4}$ ratio equal to 1, and then inserted into the ERV-100 reactor that simulates the characteristics of a continuous tubular (PBR). The reforming reaction is endothermic and operated at $650{ }^{\circ} \mathrm{C}$. After the end of the reaction, the steam was cooled to a temperature of $50{ }^{\circ} \mathrm{C}$, and the synthesis gas and residual reactants separated.

\subsection{Dry and Steam Methane Reform via Biogas}

In these processes, the same flowchart configurations of the dry and steam methane reforming processes were used, as can be seen in Fig. 3a and Fig. 3b, respectively. The only difference was the use of biogas as a reagent in place of $\mathrm{CH}_{4}$. Methane, $\mathrm{CO}_{2}$, water, $\mathrm{CO}$, and hydrogen components have been added to the software for the simulation. Biogas was composed of $70 \% \mathrm{CH}_{4}$ and $30 \% \mathrm{CO}_{2}$, according to [46]. The contaminants influence $\left(\mathrm{NH}_{4}, \mathrm{NH}_{3}\right.$, and $\left.\mathrm{H}_{2} \mathrm{~S}\right)$ that compose the biogas was not considered. Table 4 presents the operational conditions of the input streams of the Biogas, $\mathrm{CO}_{2}, \mathrm{~N}_{2}$, and $\mathrm{H}_{2} \mathrm{O}$ reagents. 


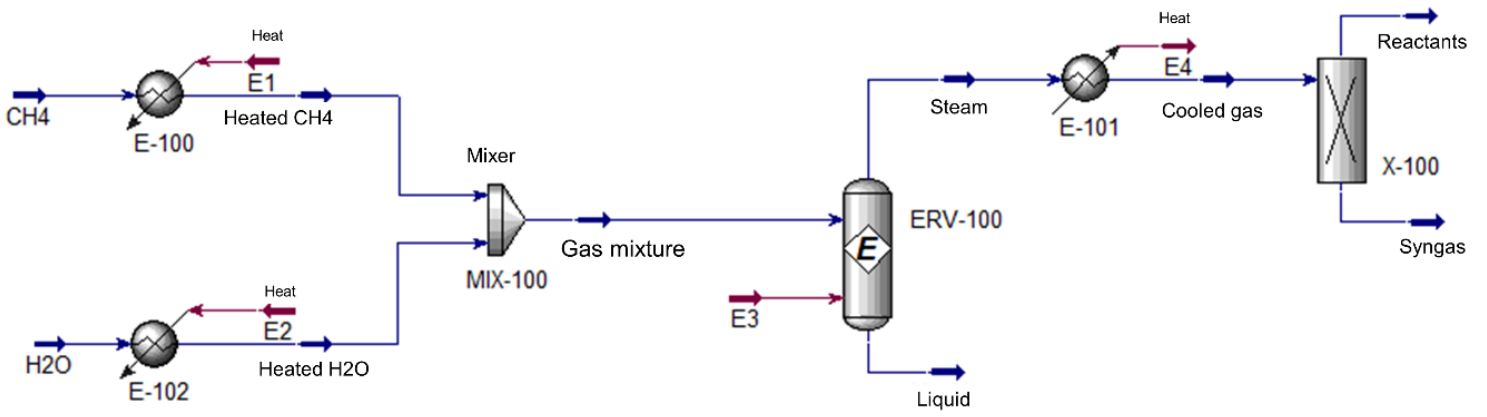

Fig. 2. Aspen HYSYS flow-sheet for Steam reforming of Methane.

a)

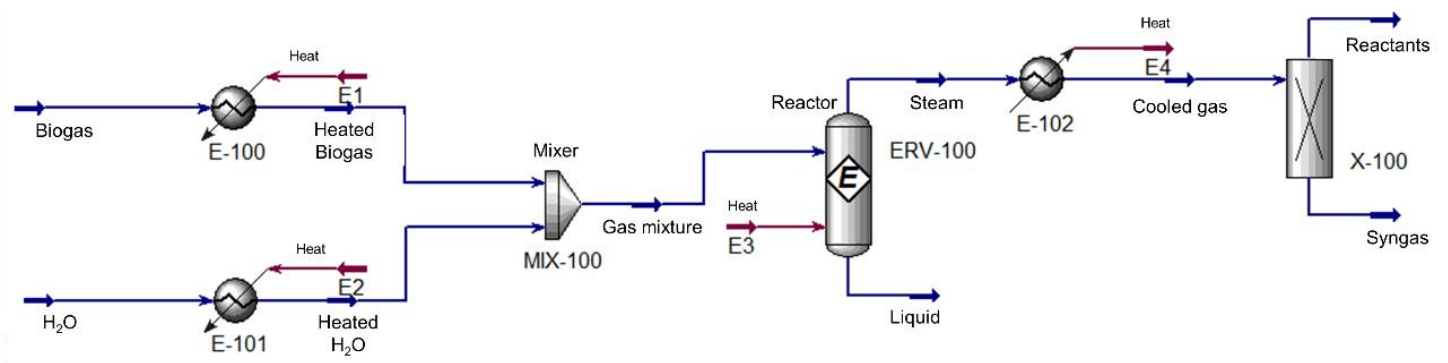

b)

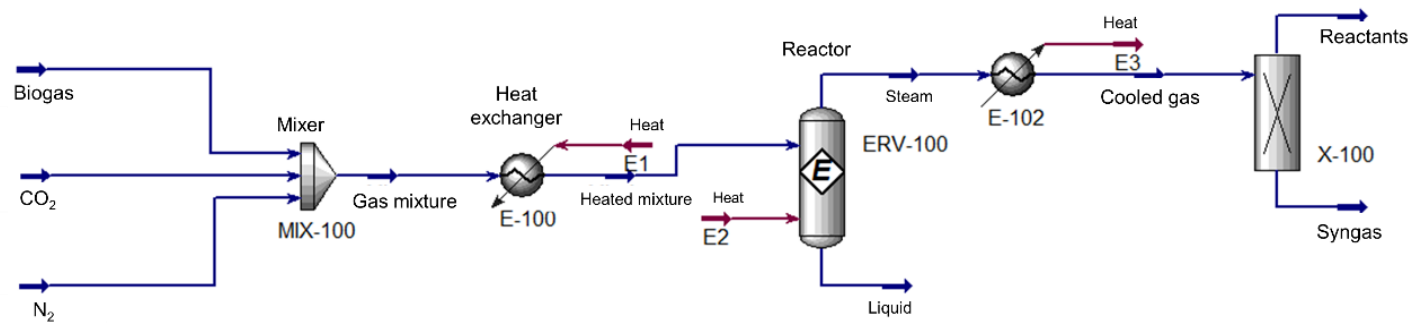

Fig. 3. Aspen HYSYS flow-sheet, a) Steam Reforming of Biogas, b) Dry Reforming of Biogas.

Table 4. Specifications for the input streams - Biogas Reforming.

\begin{tabular}{ccccc}
\hline Parameter & $\mathbf{N}_{2}$ & $\mathbf{C O}_{2}$ & $\mathbf{H}_{2} \mathbf{O}$ & Biogas \\
\hline Flow rate $(\mathrm{kgmol} / \mathrm{h})$ & 200 & 1000 & 1000 & 1000 \\
Temperature $\left({ }^{\circ} \mathrm{C}\right)$ & 25 & 25 & 25 & 25 \\
Pressure $(\mathrm{Bar})$ & 1 & 1 & 1 & 1 \\
\hline
\end{tabular}

The reaction used in the dry reforming simulation via biogas was the main dry reforming reaction (R1). For the steam reforming via biogas, they were added to the steam and dry reforming reactions (R1 and R2) due to the presence in the process of the reactants for both reactions. The reaction that forms carbon deposition as a function of the temperature used for the reaction $\left(650{ }^{\circ} \mathrm{C}\right)$ was neglected.

\subsection{Parametric Investigations}

Parametric sensitivity analysis with two hundred computational experiments based on the four processes was performed. To evaluate the parameter's influence in the conversion of methane in the reform reactors, a sensitivity analysis was carried out in the individual processes. The parameters studied were: the influence of operating temperature, operating pressure, and the $\mathrm{CO}_{2} / \mathrm{CH}_{4}$, $\mathrm{CO}_{2}$ /Biogas, $\mathrm{H}_{2} \mathrm{O} / \mathrm{CH}_{4}$, and $\mathrm{H}_{2} \mathrm{O} / \mathrm{Biogas}$ ratios on the methane conversion. The system analyzed the influence, mainly, of temperature on equilibrium in general, as well as pressure and molar proportion of feed in the reactor.

The parameters chosen for the simulation were for a temperature range of 600 to $1000{ }^{\circ} \mathrm{C}$, molar fractions of $\mathrm{CO}_{2}-\mathrm{H}_{2} \mathrm{O} / \mathrm{CH}_{4}$ and $\mathrm{CO}_{2}-\mathrm{H}_{2} \mathrm{O} / \mathrm{Biogas}$ feed were from 1 to 5 , and pressures from 1 bar to 5 bar [47]. 
For the analysis, the molar ratio was varied, keeping the $\mathrm{CH}_{4}$ and Biogas constant and modifying the input of the other reagent. For the temperature analysis influence, the pressure constant at 1 bar and the molar ratio, and the temperature were modified. Values were obtained for all molar ratios (1$5)$. In the molar ratio influence analysis, the pressure constant at 1 bar and the temperature values were obtained for each temperature $\left(600-1000{ }^{\circ} \mathrm{C}\right)$. The constant temperature at $700{ }^{\circ} \mathrm{C}$ and the molar ratio for the pressure influence analysis, obtaining values for each molar ratio.

\section{Results and Discussion}

In the following sections, the dry and steam reforming processes are discussed separately, focusing on the analysis of the effects of temperature, pressure, and the ratio of reactants at the reactor inlet. In addition, the impact of replacing methane with biogas is evaluated.

\subsection{Dry Reforming - Methane and Biogas}

The results obtained in the dry reforming simulations for both methane and biogas are presented in Fig. 4(a-f). The results as a function of temperature (Fig. 4a and Fig. 4b) indicated that for the simulated interval, methane conversion increases as the temperature increase, independently of the simulated molar ratio. It shows that higher temperatures favor methane conversion. The use of biogas proved to be favorable for the process yield, as can be seen in the comparison of the reform using a molar ratio equal to 5 (green curves in Fig. $4 \mathrm{a}$ and Fig. 4b).

Considering the effects of changing the molar ratio of the reactants (Fig. 4c and Fig. 4d), it was observed that at the lowest temperature simulated $\left(600^{\circ} \mathrm{C}\right)$, the results obtained for dry reforming and biogas dry reforming were of $44 \%$ and $58 \%$, respectively, at a molar ratio equal to 1 . For the highest molar ratio and the same temperature $\left(5,600{ }^{\circ} \mathrm{C}\right)$, the result obtained for dry methane reforming was $88 \%$, and for biogas, dry reforming was $92 \%$ conversion. This indicates that increasing the $\mathrm{CO}_{2} / \mathrm{CH}_{4}$ or $\mathrm{CO}_{2} /$ Biogas molar ratio, under constant pressure $\left(1 \mathrm{bar}\right.$ ) and low temperatures (under $800{ }^{\circ} \mathrm{C}$ ), favors the conversion of methane, which can be seen in red and black curves in Fig. 4c and Fig. 4d. However, at temperatures above $800^{\circ} \mathrm{C}$, no significant influence of molar ratio increase was observed (except $800^{\circ} \mathrm{C} \mathrm{CO}_{2} / \mathrm{CH}_{4}=1$ ). The same behavior was observed at other pressures. Thus, the simulation results suggest that it is possible to operate at lower temperatures (which would represent savings from an energy point of view) using higher concentrations of $\mathrm{CO}_{2}$ during the reaction. Again, the best performance of Biogas in comparison to pure methane is observed, which is evident at the temperature of $600^{\circ} \mathrm{C}$ (Fig. $4 \mathrm{c}$ and Fig. 4d). However, it is necessary to consider that in the dry reforming process, it is necessary to operate at high temperatures (for example, $870{ }^{\circ} \mathrm{C}$ ) in order to avoid the formation of coke in the catalysts.

In the pressure effect analysis (Fig. 4e and Fig. 4f), it was observed that the pressure increase affected the methane dry reforming process in terms of conversion than the biogas dry reforming process. However, the increase in pressure is unfavorable for both processes. In the dry reforming process of methane, by maintaining a temperature of $700{ }^{\circ} \mathrm{C}$ and a molar ratio of $\mathrm{CO}_{2} / \mathrm{CH}_{4}$ equal to 1 constant, the conversion of methane was $76.48 \%$ at a pressure of $1 \mathrm{bar}$, decreasing at a pressure of 5 bar, to $47.07 \%$. The results obtained also show that, at constant pressure and temperature, a greater amount of $\mathrm{CO}_{2}$ is needed in the dry reforming process to have a greater conversion of methane.

This is in agreement with what has been described by other authors for the dry reforming of methane [48], who observed that the $\mathrm{CH}_{4}$ conversion increases with increasing molar ratio $(0.5-2.0)$ and temperature $\left(700-950^{\circ} \mathrm{C}\right)$ of operation. In [49], similar values were obtained with temperatures increasing from 500 to $1000^{\circ} \mathrm{C}$, and molar ratios and pressures ranging between 0.5 and 3 and between 0.5 and 50 bar, respectively. In [50], the authors studied the temperature along the length of the reactor and observed that after reaching its minimum value, the reactor temperature starts to increase, as the heat requirement is lower than in the inlet region. As the reaction is endothermic, this provides heating for the gas mixture and increases its temperature. Thus, thermodynamic equilibrium is shifted to the right side along the length of the reactor so that reaction rates do not fall to a low value and the highest conversion of methane to hydrogen can be achieved. According to [51], the appropriate increase in 
the temperature range and molar ratio increases the $\mathrm{CH}_{4}$ and $\mathrm{CO}_{2}$ conversions, as well as the yield of $\mathrm{H}_{2}$ and $\mathrm{CO}$ due to the reaction being endothermic.

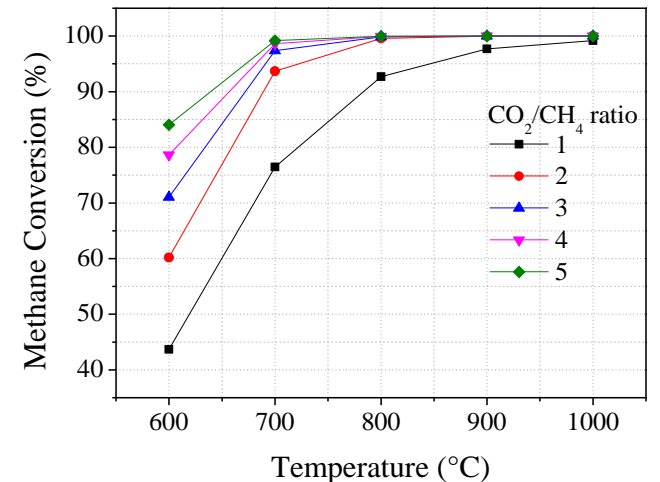

(a)

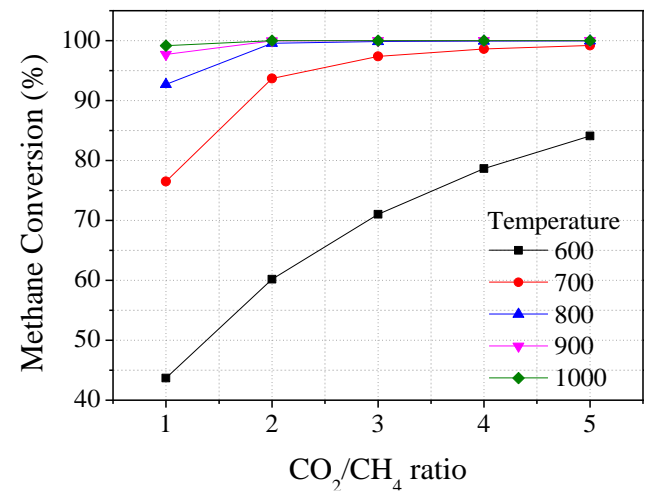

(c)

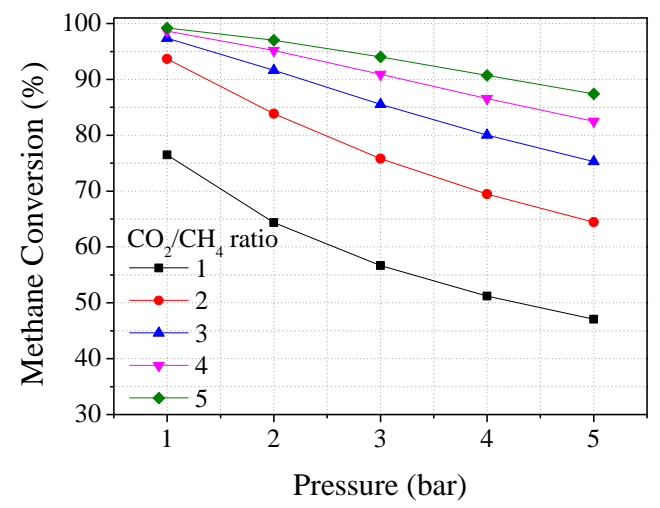

(e)

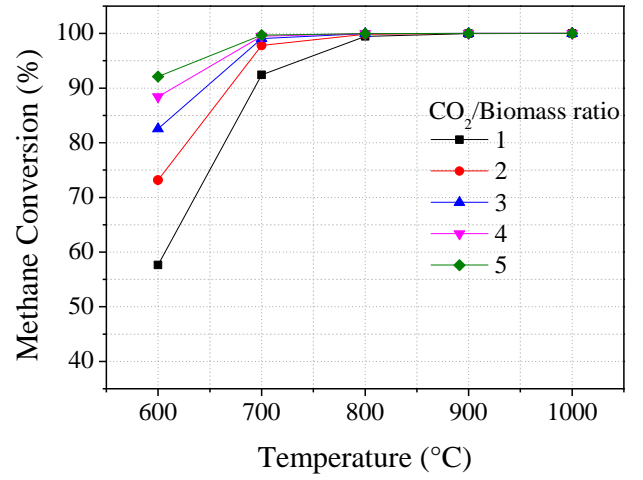

(b)

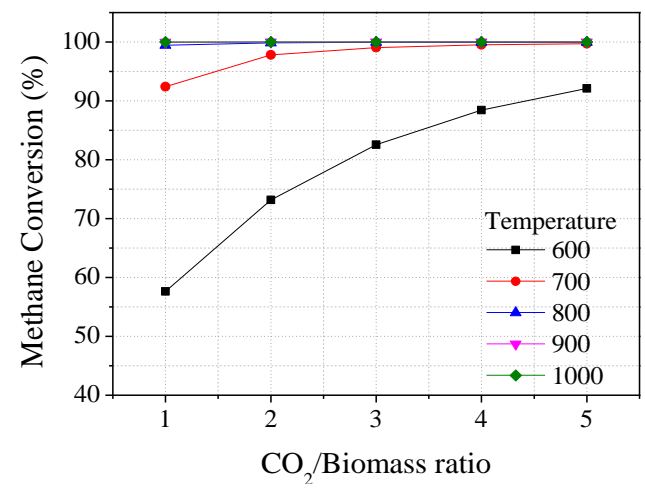

(d)

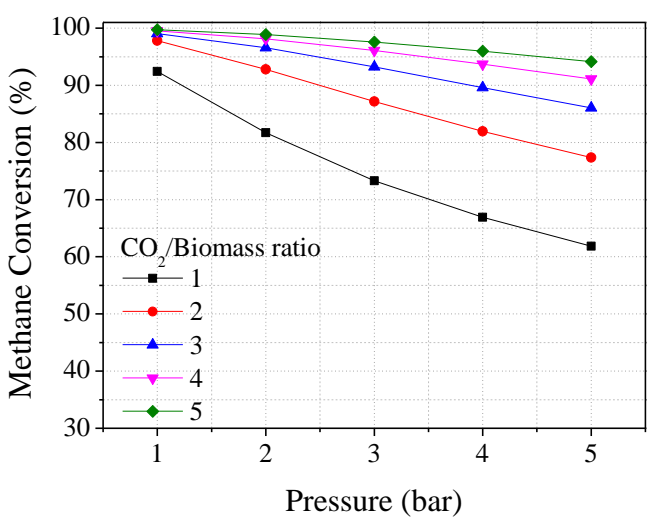

(f)

Fig. 4. Methane conversion in the dry reforming process of methane and biogas as a function of temperature (a and b), molar ratio $\mathrm{CO}_{2} / \mathrm{CH}_{4}$ (c) or $\mathrm{CO}_{2} / \operatorname{Biogas}(d)$, and of pressure (e and f).

In [52], $\mathrm{CO}_{2}$ reforming of methane (DRM) over $\mathrm{Ni} / \mathrm{g}-\mathrm{Al}_{2} \mathrm{O}_{3}$ at atmospheric pressure and temperatures between $450-650{ }^{\circ} \mathrm{C}$, was studied by a Microkinetic model. The results indicated that in the catalytic reaction, there is an adsorption competition between $\mathrm{CH}_{4}$ and $\mathrm{CO}_{2}$ in metallic $\mathrm{Ni}$ sites. They observed that at low temperatures $\left(450\right.$ and $\left.500{ }^{\circ} \mathrm{C}\right)$, the surface was mainly covered by $\mathrm{CH}_{4}{ }^{*}$. Furthermore, above $550{ }^{\circ} \mathrm{C}$, we observe that the dissociation of $\mathrm{CH}_{4} *$ to $\mathrm{CH}_{3} *$ becomes more significant, whereas, at higher temperatures $\left(650^{\circ} \mathrm{C}\right), \mathrm{CH}_{4} *$ rapidly decreases, leading to nickel-free sites. 
High values in the $\mathrm{CO}_{2} / \mathrm{CH}_{4}$ or $\mathrm{CO}_{2} /$ biogas ratio, high temperatures, and low pressures favor the maximum conversion of methane. In [53]-[55], the thermodynamics of dry biogas reforming was investigated by varying the parameters of temperature, molar ratio, and pressure using the Gibbs free energy minimization method. When other conditions were kept the same, $\mathrm{CH}_{4}$ conversion increased with increasing temperature and with increasing molar ratio. Although the high temperature is believed to improve the conversion of $\mathrm{CH}_{4}$ and $\mathrm{CO}_{2}$, many researchers are looking for new ways to reduce the high energy consumption derived from high temperatures.

\subsection{Steam Reforming - Methane and Biogas}

Fig. 5 (a-f) shows the methane conversion values obtained by simulating the steam reforming of methane and biogas. It was observed that, for the simulated interval, the conversion of methane is greater for higher temperature values (Fig. 5a and Fig. 5b), a behavior similar to that shown in the dry methane reform. Regarding the molar ratios $\mathrm{H}_{2} \mathrm{O} / \mathrm{CH}_{4}$ and $\mathrm{H}_{2} \mathrm{O} /$ Biogas, for all simulated temperatures (Fig. 5c and Fig. 5d), it was observed that the increase in the molar ratio causes the increase in the conversion of methane. At a temperature of $600{ }^{\circ} \mathrm{C}$ and the constant pressure of $1 \mathrm{bar}$, the conversion of methane was $46.85 \%$ at $\mathrm{H}_{2} \mathrm{O} / \mathrm{CH}_{4}$ molar ratio equal to 1 and $87.85 \%$ for $\mathrm{H}_{2} \mathrm{O} / \mathrm{CH}_{4}$ molar ratio equal to 5 .

As for pressure (Fig. 5e and Fig. 5f), it was observed that the methane conversion was higher for lower pressure values, considering the simulated range, independent of the simulated molar ratio for both processes, indicating that high pressures do not favor the methane conversion.

Thus, the results obtained show that, at constant pressure and temperature, a greater amount of $\mathrm{H}_{2} \mathrm{O}$ is required in the steam reforming process to have greater methane conversion. High values in the $\mathrm{H}_{2} \mathrm{O} / \mathrm{CH}_{4}$ ratio, high temperatures, and low pressures favor the maximum conversion of methane. The steam reforming reaction is endothermic and increases with increasing entropy. The increase in temperature makes the reaction more favorable. The steam reforming methane reaction is favored by expansion, so pressure decreasing results in an increase in methane conversion. According to [56], the methane conversion increases as the temperature increases $\left(700-1000{ }^{\circ} \mathrm{C}\right)$, the pressure decreases $(1$ - 20 bar), and as the molar ratio of $\mathrm{H}_{2} \mathrm{O} / \mathrm{CH}_{4}$ reactants increases $(0.5-5)$.

It was observed that at constant pressure and temperature, a greater amount of $\mathrm{H}_{2} \mathrm{O}$ is needed in the steam reforming process via biogas to have greater methane conversion (Fig. $5 \mathrm{c}$ and Fig. 5d). High values in the $\mathrm{H}_{2} \mathrm{O} / \mathrm{Biogas}$ ratio, high temperatures, and low pressures favor the maximum conversion of methane. Reaction conditions have a large effect on the biogas vapor reforming process. In [57] and [58] works, the effects of molar ratio $(0.9-2.9)$, temperature $\left(500-1000{ }^{\circ} \mathrm{C}\right)$, and pressure $(0.5$ 6 bar) in thermodynamic equilibrium were investigated. For all molar ratios, $\mathrm{CH}_{4}$ conversion increased with increasing temperature due to the endothermic nature of methane steam reforming. Almost all $\mathrm{CH}_{4}$ was consumed above $850{ }^{\circ} \mathrm{C}$, except for the lowest molar ratio (0.9). This indicates that the oxidizing agents were limiting reagents, such that insufficient amounts of oxidizing agents caused a lower $\mathrm{CH}_{4}$ conversion. A high reaction temperature $\left(\geq 500{ }^{\circ} \mathrm{C}\right)$ and a high molar ratio of reactants $\left(\mathrm{CO}_{2}+\mathrm{H}_{2} \mathrm{O}\right)$ to $\mathrm{CH}_{4}$ and low pressures are required for the steam reforming of biogas to prevent coke formation and have high methane conversion. The addition of $\mathrm{H}_{2} \mathrm{O}$ to biogas reduces coke formation due to its ability to initiate reactions that result in coke destruction. In [50], a thermodynamic equilibrium analysis was performed to determine the most appropriate operating conditions that are thermodynamically favored for steam reforming of biogas. High pressures and temperatures were used for the thermodynamic simulation (10 and 40 bar / 973 and $1173 \mathrm{~K}$ ). According to the balance results, the functioning pressure shows a negative effect on steam reforming of biogas at a fixed temperature. In contrast, the operating temperature has a positive effect on $\mathrm{CH}_{4}$ conversion and $\mathrm{H}_{2}$ yield. 


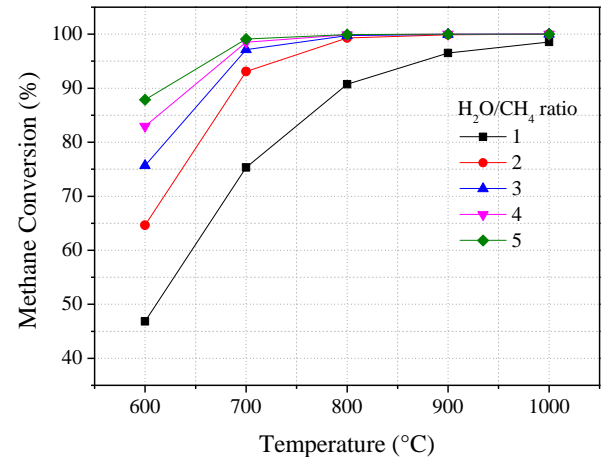

(a)

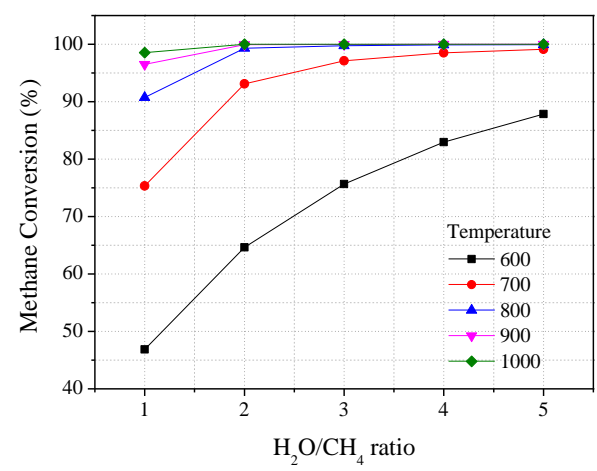

(c)

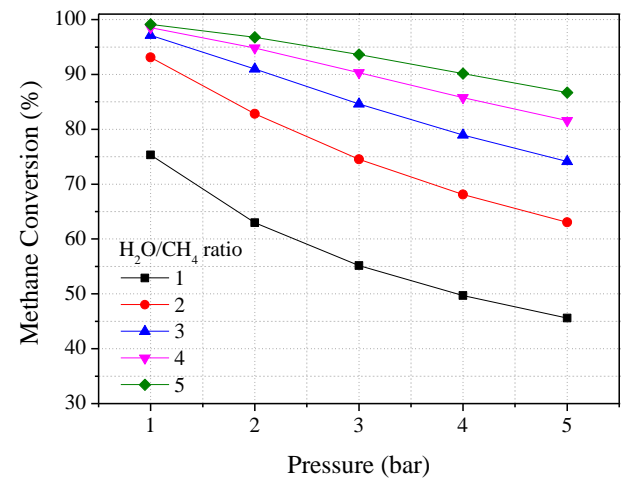

(e)

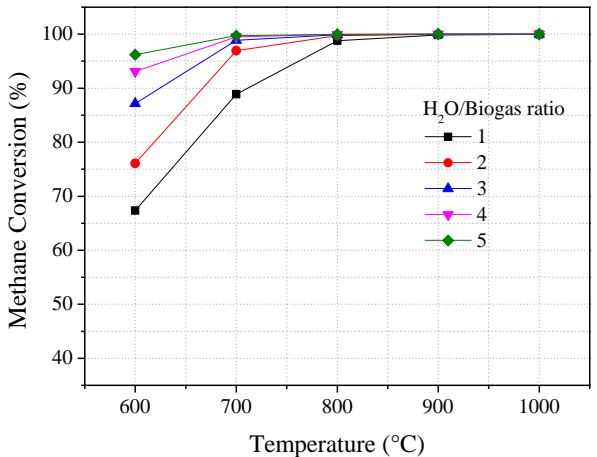

(b)

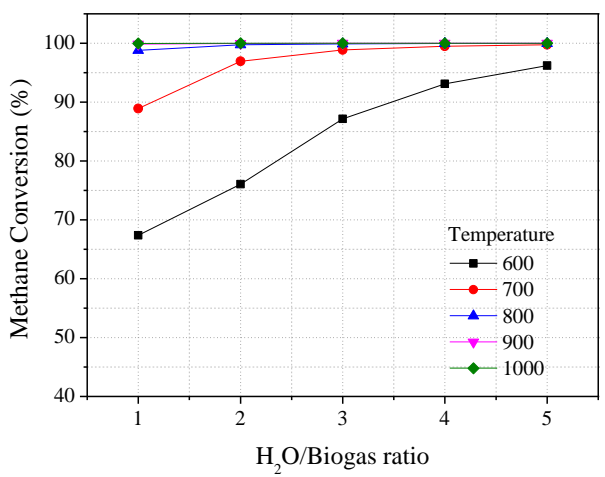

(d)

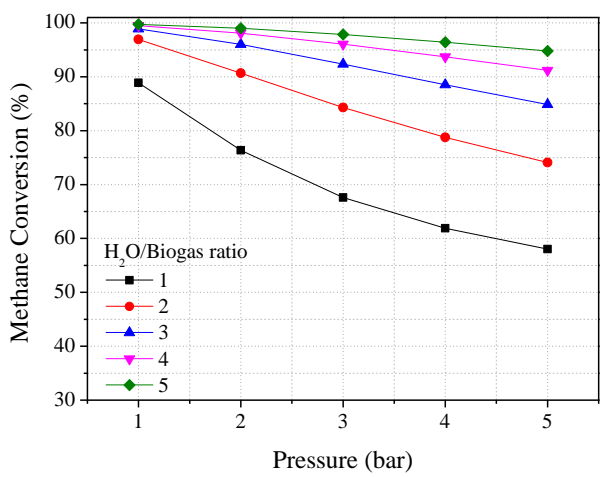

(f)

Fig. 5. Methane conversion in the steam reforming process of methane and biogas as a function of temperature (a and b), molar ratio $\mathrm{CO}_{2} / \mathrm{CH}_{4}(\mathrm{c})$ or $\mathrm{CO}_{2} /$ Biogas $(\mathrm{d})$, and of pressure (e and $\mathrm{f}$ ).

\subsection{Parametric Sensitivity Analysis}

Fig. 6 shows a comparison of the temperature influence (Fig. 6a), the molar ratio (Fig. 6b), and pressure (Fig. 6c) on the processes simulated in this study. It was observed that the biogas reform processes showed better conversion values compared to the process with pure methane when there was an increase in temperature (Fig. 6a). In the temperature of $600{ }^{\circ} \mathrm{C}$ (molar ratio 1), the methane conversion in the biogas steam reforming obtained a higher conversion. On the other hand, with the increase in temperature (from $700{ }^{\circ} \mathrm{C}$ ), the dry biogas reforming indicated a greater conversion of methane. 


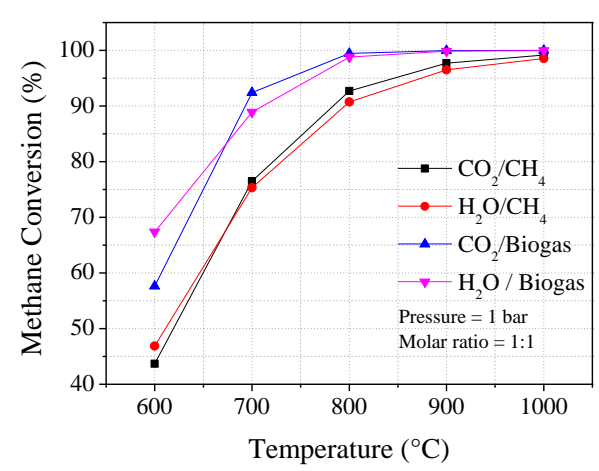

(a)

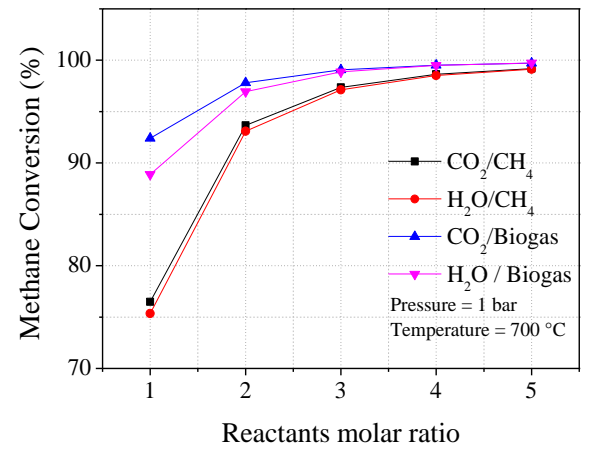

(b)

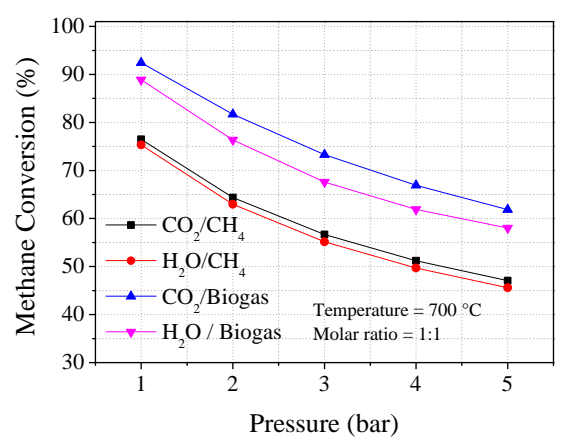

(c)

Fig. 6. Methane conversion in different processes as a function of (a) temperature (1 bar and 1/1 molar ratio); (b) molar ratio $\left(1 \mathrm{bar}\right.$ and $\left.700^{\circ} \mathrm{C}\right)$; and pressure $\left(700^{\circ} \mathrm{C}\right.$ and $1 / 1$ molar ratio)

However, the methane conversion was higher for higher temperature values, showing the positive effect of increasing the temperature on the conversion, independent of the methane source used to obtain the syngas. When setting the temperature and pressure values, it was observed that the conversion of methane increases with the increase in the molar proportion of reactants, in all processes, with a more significant variation being observed in both dry and steam reforming processes that employed pure methane (Fig. 6b). Fig. 6c indicates that the use of biogas as a reagent to replace pure methane in a molar ratio equal to 1 showed better results. This is due to the biogas having a smaller amount of methane, favoring the reaction, a higher proportion favoring the conversion of methane (Fig. 6c).

\section{Conclusions}

Based on simulations carried out in the Aspen Plus software, it was possible to analyze the dry/steam reforming processes, using pure methane or biogas as raw materials for comparison purposes. Regarding the effects of the operational parameters, the results indicated that by means of the open-loop control of the pressure and temperature, the methane conversion increases with a higher proportion of $\mathrm{CO}_{2} / \mathrm{CH}_{4}, \mathrm{CO}_{2} / \mathrm{Biogas}, \mathrm{CO}_{2} / \mathrm{CH}_{4}$, and $\mathrm{H}_{2} \mathrm{O} / \mathrm{Biogas}$. At constant pressure and the molar ratio of $\mathrm{CO}_{2} / \mathrm{CH}_{4}, \mathrm{CO}_{2} / \mathrm{Biogas}, \mathrm{CO}_{2} / \mathrm{CH}_{4}$, and $\mathrm{CO}_{2} / \mathrm{Biogas}$, the methane conversion increases with increasing temperature. On the other hand, with constant temperature and molar ratio of $\mathrm{CO}_{2} / \mathrm{CH}_{4}$, $\mathrm{CO}_{2} / \mathrm{Biogas}, \mathrm{CO}_{2} / \mathrm{CH}_{4}$, and $\mathrm{CO}_{2} / \mathrm{Biogas}$, the conversion of methane decreased with increasing pressure.

Comparing methane and biogas as raw materials for the reforming process, the simulation results indicated that the latter is quite advantageous, favoring higher conversions. This is due to the composition of Biogas, which contains a mixture of $\mathrm{CH}_{4}$ and $\mathrm{CO}_{2}$. As can be concluded from the analyzes carried out regarding the reactant's molar ratios, a higher $\mathrm{CO}_{2} / \mathrm{CH}_{4}$ molar ratio at the entrance 
of the reactor favors a greater methane conversion. When using Biogas instead of pure $\mathrm{CH}_{4}$, the fraction of $\mathrm{CO}_{2}$ that composes the Biogas is introduced into the reactor together with methane, which favors the efficiency of the reform. The use of biogas in replacement of pure methane in the methane reform process is an alternative with great potential given the need to add value to a residue, and its conditions favor the reaction of syngas production.

From the present results, future studies can be carried out seeking a better understanding of the effects of the biogas composition on the reforming process performance, mainly with regard to a systematic comparison of Biogas produced from different residues.

Author Contribution: All authors contributed equally to the main contributor to this paper. All authors read and approved the final paper.

Acknowledgment: The authors acknowledge the support from the Brazilian agencies CAPES, FA, and CNPq.

Conflicts of Interest: The authors declare that there is no conflict of interest regarding the publication of this paper. Additionally, the authors declare their data available for researchers and are available with the corresponding author.

\section{References}

[1] V. P. Oktyabrskiy, "A new opinion of the greenhouse effect," St. Petersbg. Polytech. Univ. J. Phys. Math., vol. 2, no. 2, pp. 124-126, Jun. 2016, https://doi.org/10.1016/j.spjpm.2016.05.008.

[2] J. K. Dahl, J. Tamburini, A. W. Weimer, A. Lewandowski, R. Pitts, and C. Bingham, "Solar-Thermal Processing of Methane to Produce Hydrogen and Syngas," Energy \& Fuels, vol. 15, no. 5, pp. 12271232, Sep. 2001, https://doi.org/10.1021/ef0100606.

[3] T. Jiang, X. Ma, Q. Tang, J. Yang, G. Li, and F. Schuchardt, "Combined use of nitrification inhibitor and struvite crystallization to reduce the $\mathrm{NH} 3$ and $\mathrm{N} 2 \mathrm{O}$ emissions during composting," Bioresour. Technol., vol. 217, pp. 210-218, Oct. 2016, https://doi.org/10.1016/j.biortech.2016.01.089.

[4] Y. Luo, G. Li, W. Luo, F. Schuchardt, T. Jiang, and D. Xu, "Effect of phosphogypsum and dicyandiamide as additives on NH3, N2O and CH4 emissions during composting," J. Environ. Sci., vol. 25, no. 7, pp. 1338-1345, Jul. 2013, https://doi.org/10.1016/S1001-0742(12)60126-0.

[5] P. Nikolaidis and A. Poullikkas, "A comparative overview of hydrogen production processes," Renew. Sustain. Energy Rev., vol. 67, pp. 597-611, Jan. 2017, https://doi.org/10.1016/j.rser.2016.09.044.

[6] X. Yang, J. Da, H. Yu, and H. Wang, "Characterization and performance evaluation of Ni-based catalysts with Ce promoter for methane and hydrocarbons steam reforming process," Fuel, vol. 179, pp. 353-361, Sep. 2016, https://doi.org/10.1016/j.fuel.2016.03.104.

[7] G. G. Lenzi, E. K. Lenzi, C. V. B. Fávero, M. K. Lenzi, R. M. M. Jorge, O. A. A. dos Santos, and L. M. M. Jorge, "Simulation Studies of Steam Reforming of Methane using Ni-Al2O3 Catalysts," Int. J. Chem. React. Eng., vol. 8, no. 1, Feb. 2010, https://doi.org/10.2202/1542-6580.2110.

[8] R. A. El-Salamony, S. A. El-Temtamy, A. M. A. El Naggar, S. A. Ghoneim, D. R. Abd El-Hafiz, M. A. Ebiad, T. Gendy, and A. M. Al-Sabagh, "Valuation of catalytic activity of nickel-zirconia-based catalysts using lanthanum co-support for dry reforming of methane," Int. J. Energy Res., vol. 45, no. 3, pp. 38993912, Mar. 2021, https://doi.org/10.1002/er.6043.

[9] A. Azizzadeh Fard, A. Bazyari, S. M. Alavi, and A. R. Aghamiri, "The effects of cobalt and cerium promoters on hydrogen production performance of alumina-supported nickel catalysts in propane steam reforming," J. Chem. Technol. Biotechnol., vol. 95, no. 12, pp. 3241-3251, Dec. 2020, https://doi.org/10.1002/jctb.6503.

[10] J. N. Armor, "The multiple roles for catalysis in the production of H2," Appl. Catal. A Gen., vol. 176, no. 2, pp. 159-176, Jan. 1999, https://doi.org/10.1016/S0926-860X(98)00244-0.

[11] T. Ohkubo, Y. Hideshima, and Y. Shudo, "Estimation of hydrogen output from a full-scale plant for production of hydrogen from biogas," Int. J. Hydrogen Energy, vol. 35, no. 23, pp. 13021-13027, Dec. 2010, https://doi.org/10.1016/j.ijhydene.2010.04.063. 
[12] O. A. Bereketidou and M. A. Goula, "Biogas reforming for syngas production over nickel supported on ceria-alumina catalysts," Catal. Today, vol. 195, no. 1, pp. 93-100, Nov. 2012, https://doi.org/10.1016/j.cattod.2012.07.006.

[13] A. Baccioli, M. Antonelli, S. Frigo, U. Desideri, and G. Pasini, "Small scale bio-LNG plant: Comparison of different biogas upgrading techniques," Appl. Energy, vol. 217, pp. 328-335, May 2018, https://doi.org/10.1016/j.apenergy.2018.02.149.

[14] T. Rehl and J. Müller, "CO2 abatement costs of greenhouse gas (GHG) mitigation by different biogas conversion pathways," J. Environ. Manage., vol. 114, pp. 13-25, Jan. 2013, https://doi.org/10.1016/j.jenvman.2012.10.049.

[15] P. Weiland, "Biogas production: current state and perspectives," Appl. Microbiol. Biotechnol., vol. 85, no. 4, pp. 849-860, Jan. 2010, https://doi.org/10.1007/s00253-009-2246-7.

[16] W. Yin, N. Guilhaume, and Y. Schuurman, "Model biogas reforming over Ni-Rh/MgA12O4 catalyst. Effect of gas impurities," Chem. Eng. J., vol. 398, p. 125534, Oct. 2020, https://doi.org/10.1016/j.cej.2020.125534.

[17] M. P. Kohn, J. Lee, M. L. Basinger, and M. J. Castaldi, "Performance of an Internal Combustion Engine Operating on Landfill Gas and the Effect of Syngas Addition," Ind. Eng. Chem. Res., vol. 50, no. 6, pp. 3570-3579, Mar. 2011, https://doi.org/10.1021/ie101937s.

[18] L. E. Øi and J. Hovland, "Simulation of Condensation in Compressed Raw Biogas Using Aspen HYSYS," Nov. 2018, pp. 31-36, https://doi.org/10.3384/ecp1815331.

[19] G. Ye, D. Xie, W. Qiao, J. R. Grace, and C. J. Lim, "Modeling of fluidized bed membrane reactors for hydrogen production from steam methane reforming with Aspen Plus," Int. J. Hydrogen Energy, vol. 34, no. 11, pp. 4755-4762, Jun. 2009, https://doi.org/10.1016/j.ijhydene.2009.03.047.

[20] D. Chaconas, P. Pichardo, I. V. Manousiouthakis, and V. I. Manousiouthakis, "Equilibrium analysis of $\mathrm{CH} 4, \mathrm{CO}, \mathrm{CO} 2, \mathrm{H} 2 \mathrm{O}, \mathrm{H} 2, \mathrm{C}$ mixtures in $\mathrm{C}-\mathrm{H}-\mathrm{O}$ atom space using Gibbs free energy global minimization," AIChE Annu. Meet. Conf. Proc., vol. 2020-Novem, no. September, 2020, https://doi.org/10.1002/aic.17052.

[21] Y. Haseli, "Criteria for chemical equilibrium with application to methane steam reforming," Int. J. Hydrogen Energy, vol. 44, no. 12, pp. 5766-5772, 2019, https://doi.org/10.1016/j.ijhydene.2019.01.130.

[22] H. Nourbakhsh, J. Rahbar Shahrouzi, H. Ebrahimi, and A. Zamaniyan, "Experimental study of ultra-rich thermal partial oxidation of methane using a reticulated porous structure," Int. J. Hydrogen Energy, vol. 45, no. 22, pp. 12298-12307, 2020, https://doi.org/10.1016/j.ijhydene.2020.02.182.

[23] H. Nourbakhsh, J. Rahbar Shahrouzi, A. Zamaniyan, H. Ebrahimi, and M. R. Jafari Nasr, "A thermodynamic analysis of biogas partial oxidation to synthesis gas with emphasis on soot formation," Int. J. Hydrogen Energy, vol. 43, no. 33, pp. 15703-15719, 2018, https://doi.org/10.1016/j.ijhydene.2018.06.134.

[24] A. Vita, C. Italiano, D. Previtali, C. Fabiano, A. Palella, F. Freni, G. Bozzano, L. Pino, and F. Manenti, "Methanol synthesis from biogas: A thermodynamic analysis," Renew. Energy, vol. 118, pp. 673-684, 2018, https://doi.org/10.1016/j.renene.2017.11.029.

[25] W. Fuqiang, J. Lin, C. Ziming, L. Huaxu, and T. Jianyu, "Combination of thermodynamic analysis and regression analysis for steam and dry methane reforming," Int. J. Hydrogen Energy, pp. 15795-15810, 2019, https://doi.org/10.1016/j.ijhydene.2018.05.177.

[26] P. A. Pichardo and V. I. Manousiouthakis, "Intensified energetically enhanced steam methane reforming through the use of membrane reactors," AIChE J., vol. 66, no. 2, 2020, https://doi.org/10.1002/aic.16827.

[27] V. R. Bach, A. C. de Camargo, T. L. de Souza, L. Cardozo-Filho, and H. J. Alves, "Dry reforming of methane over $\mathrm{Ni} / \mathrm{MgO}-\mathrm{Al} 2 \mathrm{O} 3$ catalysts: Thermodynamic equilibrium analysis and experimental application," Int. J. Hydrogen Energy, vol. 45, no. 8, pp. 5252-5263, 2020, https://doi.org/10.1016/j.ijhydene.2019.07.200.

[28] M. D. Özcan, O. Özcan, and A. N. Akın, "Thermodynamic modelling and optimization of oxy-reforming and oxy-steam reforming of biogas by RSM," Environ. Technol. (United Kingdom), vol. 41, no. 1, pp. 14-28, 2020, https://doi.org/10.1080/09593330.2019.1639828. 
[29] D. Pashchenko, "First law energy analysis of thermochemical waste-heat recuperation by steam methane reforming," Energy, vol. 143, pp. 478-487, 2018, https://doi.org/10.1016/j.energy.2017.11.012.

[30] D. Pashchenko, "Combined methane reforming with a mixture of methane combustion products and steam over a Ni-based catalyst: An experimental and thermodynamic study," Energy, vol. 185, pp. 573584, 2019, https://doi.org/10.1016/j.energy.2019.07.065.

[31] M. K. P. Mustafa Kamal Pasha, I. A. Iftikhar Ahmad, J. M. Jawad Mustafa, and M. K. Manabu Kano, "Modeling of a Nickel-based Fluidized Bed Membrane Reactor for Steam Methane Reforming Process," J. Chem. Soc. pakistan, vol. 41, no. 2, pp. 219-219, 2019, https://doi.org/10.52568/000729/JCSP/41.02.2019.

[32] C. Jensen and M. S. Duyar, "Thermodynamic Analysis of Dry Reforming of Methane for Valorization of Landfill Gas and Natural Gas," Energy Technol., vol. 9, no. 7, pp. 1-12, 2021, https://doi.org/10.1002/ente.202100106.

[33] L. Yu, M. Song, P. T. Williams, and Y. Wei, “Optimized Reforming of Biomass Derived Gas Based on Thermodynamic and Kinetics Analysis with Activated Carbon Fibers Supported Ni-A12O3," Bioenergy Res., vol. 13, no. 2, pp. 581-590, 2020, https://doi.org/10.1007/s12155-019-10087-6.

[34] M. Parente, M. A. Soria, and L. M. Madeira, "Hydrogen and/or syngas production through combined dry and steam reforming of biogas in a membrane reactor: A thermodynamic study," Renew. Energy, vol. 157, pp. 1254-1264, 2020, https://doi.org/10.1016/j.renene.2020.05.023.

[35] X. Chen, J. Jiang, K. Li, S. Tian, and F. Yan, "Energy-efficient biogas reforming process to produce syngas: The enhanced methane conversion by O2," Appl. Energy, vol. 185, pp. 687-697, 2017, https://doi.org/10.1016/j.apenergy.2016.10.114.

[36] N. Chatrattanawet, D. Saebea, S. Authayanun, A. Arpornwichanop, and Y. Patcharavorachot, "Performance and environmental study of a biogas-fuelled solid oxide fuel cell with different reforming approaches," Energy, vol. 146, pp. 131-140, 2018, https://doi.org/10.1016/j.energy.2017.06.125.

[37] Z. Xu and S. I. Sandler, "Temperature-dependent parameters and the Peng-Robinson equation of state," Ind. Eng. Chem. Res., vol. 26, no. 3, pp. 601-606, Mar. 1987, https://doi.org/10.1021/ie00063a030.

[38] J. Solsvik, T. Haug-Warberg, and H. A. Jakobsen, "Implementation of chemical reaction equilibrium by Gibbs and Helmholtz energies in tubular reactor models: Application to the steam-methane reforming process," Chem. Eng. Sci., vol. 140, pp. 261-278, Feb. 2016, https://doi.org/10.1016/j.ces.2015.10.011.

[39] G. Gonçalves, F. Q. Martinelli, C. M. M. Costa, L. M. de M. Jorge, and O. A. A. dos Santos, "Catalisadores sol-gel de Ni-SiO2 e Ni-A12O3 aplicados na reforma de metano com CO2," Acta Sci. Technol., vol. 27, no. 1, 2005, https://doi.org/10.4025/actascitechnol.v27i1.1492.

[40] C. S. Lau, A. Tsolakis, and M. L. Wyszynski, "Biogas upgrade to syn-gas (H2-CO) via dry and oxidative reforming," Int. J. Hydrogen Energy, vol. 36, no. 1, pp. 397-404, Jan. 2011, https://doi.org/10.1016/j.ijhydene.2010.09.086.

[41] Y. Kathiraser, U. Oemar, E. T. Saw, Z. Li, and S. Kawi, "Kinetic and mechanistic aspects for CO2 reforming of methane over Ni based catalysts," Chem. Eng. J., vol. 278, pp. 62-78, Oct. 2015, https://doi.org/10.1016/j.cej.2014.11.143.

[42] D. Pashchenko, "Thermodynamic equilibrium analysis of combined dry and steam reforming of propane for thermochemical waste-heat recuperation," Int. J. Hydrogen Energy, vol. 42, no. 22, pp. 14926-14935, Jun. 2017, https://doi.org/10.1016/j.ijhydene.2017.04.284.

[43] L. Fan, L. van Biert, A. Thallam Thattai, A. H. M. Verkooijen, and P. V. Aravind, "Study of Methane Steam Reforming kinetics in operating Solid Oxide Fuel Cells: Influence of current density," Int. J. Hydrogen Energy, vol. 40, no. 15, pp. 5150-5159, Apr. 2015, https://doi.org/10.1016/j.ijhydene.2015.02.096.

[44] Q. Yuan, R. Gu, J. Ding, and J. Lu, "Heat transfer and energy storage performance of steam methane reforming in a tubular reactor," Appl. Therm. Eng., vol. 125, pp. 633-643, Oct. 2017, https://doi.org/10.1016/j.applthermaleng.2017.06.044.

[45] T. W. Kim, J. C. Park, T.-H. Lim, H. Jung, D. H. Chun, H. T. Lee, S. Hong, and J.-I. Yang, "The kinetics of steam methane reforming over a $\mathrm{Ni} / \gamma-\mathrm{Al} 2 \mathrm{O} 3$ catalyst for the development of small stationary reformers," Int. J. Hydrogen Energy, vol. 40, no. 13, pp. 4512-4518, Apr. 2015, 
https://doi.org/10.1016/j.ijhydene.2015.02.014.

[46] C. Ji, L. Gong, J. Zhang, and K. Shi, "A study on the Kinetics of the Catalytic Reforming Reaction of CH4 with CO2: Determination of the Reaction Order," J. Nat. Gas Chem., vol. 12, no. 3, pp. 201-204, 2003, https://doi.org/10.1023/A:1024904520561.

[47] S. Das, J. Ashok, Z. Bian, N. Dewangan, M. H. Wai, Y. Du, A. Borgna, K. Hidajat, and S. Kawi, "SilicaCeria sandwiched Ni core-shell catalyst for low temperature dry reforming of biogas: Coke resistance and mechanistic insights," Appl. Catal. B Environ., vol. 230, pp. 220-236, Aug. 2018, https://doi.org/10.1016/j.apcatb.2018.02.041.

[48] D. Han, Y. Kim, W. Cho, and Y. Baek, "Effect of Oxidants on Syngas Synthesis from Biogas over 3 wt $\%$ Ni-Ce-MgO-ZrO2/A12O3 Catalyst," Energies, vol. 13, no. 2, p. 297, Jan. 2020, https://doi.org/10.3390/en13020297.

[49] J. Gao, Z. Hou, H. Lou, and X. Zheng, "Dry (CO2) Reforming," in Fuel Cells: Technologies for Fuel Processing, pp. 191-221, 2011, https://doi.org/10.1016/B978-0-444-53563-4.10007-0.

[50] K. Chouhan, S. Sinha, S. Kumar, and S. Kumar, "Simulation of steam reforming of biogas in an industrial reformer for hydrogen production," Int. J. Hydrogen Energy, vol. 46, no. 53, pp. 26809-26824, Aug. 2021, https://doi.org/10.1016/j.ijhydene.2021.05.152.

[51] Y. Cui, H. Zhang, H. Xu, and W. Li, "Kinetic study of the catalytic reforming of CH4 with $\mathrm{CO} 2$ to syngas over Ni/ $\alpha$-Al2O3 catalyst: The effect of temperature on the reforming mechanism," Appl. Catal. A Gen., vol. 318, pp. 79-88, Feb. 2007, https://doi.org/10.1016/j.apcata.2006.10.044.

[52] L. Dehimi, Y. Benguerba, M. Virginie, and H. Hijazi, "Microkinetic modelling of methane dry reforming over Ni/A12O3 catalyst," Int. J. Hydrogen Energy, vol. 42, no. 30, pp. 18930-18940, Jul. 2017, https://doi.org/10.1016/j.ijhydene.2017.05.231.

[53] B. V. Ayodele and C. K. Cheng, "Process Modelling, Thermodynamic Analysis and Optimization of Dry Reforming, Partial Oxidation and Auto-Thermal Methane Reforming for Hydrogen and Syngas production," Chem. Prod. Process Model., vol. 10, no. 4, pp. 211-220, Dec. 2015, https://doi.org/10.1515/cppm-2015-0027.

[54] M. K. Nikoo and N. A. S. Amin, "Thermodynamic analysis of carbon dioxide reforming of methane in view of solid carbon formation," Fuel Process. Technol., vol. 92, no. 3, pp. 678-691, Mar. 2011, https://doi.org/10.1016/j.fuproc.2010.11.027.

[55] R. Y. Chein, Y. C. Chen, C. T. Yu, and J. N. Chung, "Thermodynamic analysis of dry reforming of CH4 with CO2 at high pressures," J. Nat. Gas Sci. Eng., vol. 26, pp. 617-629, Sep. 2015, https://doi.org/10.1016/j.jngse.2015.07.001.

[56] E. M. A. Mokheimer, M. Ibrar Hussain, S. Ahmed, M. A. Habib, and A. A. Al-Qutub, "On the Modeling of Steam Methane Reforming," J. Energy Resour. Technol., vol. 137, no. 1, Jan. 2015, https://doi.org/10.1115/1.4027962.

[57] W.-J. Jang, D.-W. Jeong, J.-O. Shim, H.-M. Kim, H.-S. Roh, I. H. Son, and S. J. Lee, “Combined steam and carbon dioxide reforming of methane and side reactions: Thermodynamic equilibrium analysis and experimental application," Appl. Energy, vol. 173, pp. 80-91, Jul. 2016, https://doi.org/10.1016/j.apenergy.2016.04.006.

[58] N. H. Elsayed, D. Maiti, B. Joseph, and J. N. Kuhn, "Precious Metal Doped Ni-Mg/Ceria-Zirconia Catalysts for Methane Conversion to Syngas by Low Temperature Bi-reforming," Catal. Letters, vol. 148, no. 3, pp. 1003-1013, Mar. 2018, https://doi.org/10.1007/s10562-018-2310-y. 